\title{
PROVA PENAL E SEGREDO PROFISSIONAL
}

\author{
CRIMINAL EVIDENCE AND PROFESSIONAL SECRECY
}

\author{
Brenno Gimenes Cesca* \\ Octavio Augusto da Silva Orzari**
}

\begin{abstract}
Resumo:
Neste texto procura-se analisar as implicações do sigilo profissional na prova penal, seara em que possui natureza de exclusão de prova por razões extraprocessuais. Dá-se ênfase à prova testemunhal e à busca e apreensão, fazendo-se observações quanto à profissão de advogados e médicos, além de referências à regulamentação da matéria no Projeto de Código de Processo Penal em tramitação no Congresso Nacional (Projeto de Lei do Senado n. 156/09). Antes, porém, na primeira parte, como antecedentes lógicos, são alinhavados problemas como a tutela da intimidade, os motivos individuais e coletivos da proteção ao sigilo profissional, do confidente necessário e do objeto do segredo, com alusões à regulamentação do direito positivo estrangeiro (Itália, Portugal, Espanha, Chile e Argentina) e do direito positivo brasileiro, desde o texto constitucional, até o regramento infralegal (portaria do Ministério da Justiça que trata da busca e apreensão em escritórios de advocacia).

Palavras-chave: Tutela da Intimidade. Sigilo profissional. Confidente necessário. Segredo. Direitos italiano, português, espanhol, chileno, argentino e brasileiro. Reflexos processuais penais do sigilo profissional. Prova testemunhal. Busca e apreensão.
\end{abstract}

\begin{abstract}
:
This paper aims to analyze the implications of professional secrecy in criminal procedure, specially on testimonial evidence and search and seizure action. Considerations about lawyers and scholars are made, as well as the rules in the new Brazilian Criminal Procedure Code draft (PLS n. 156/09). However, some material aspects are discussed, like privacy protection, reasons for professional secrecy, the necessary confidant and secrecy object, with references to the foreign substantive law (Italy, Portugal, Spain, Chile and Argentina), finalizing with the Brazilian law (from Constitution to infralegal rules).
\end{abstract}

Keywords: Protection of Intimacy. Professional secrecy. Necessary confidant. Secrecy. Italian, Portuguese, Spanish, Chilean, Argentine and Brazilian Laws. Criminal procedure reflections of professional secrecy. Testimonial evidence. Search and seizure action.

* Graduado em Direito pela PUC-Campinas. Mestre em direito pela Universidade de São Paulo. Juiz de Direito no Estado de São Paulo.

** Graduado e mestre em Direito pela Universidade de São Paulo. Pós-graduado em Direito Penal pela Universidade de Salamanca/Espanha. Pós-graduado em Ciência Política pela UnB. Advogado do Senado Federal. 
1. Introdução

Algumas profissões, como a de advogado, contadores, psicólogos, médicos, dentistas, profissionais da área da saúde de modo geral e jornalistas, ${ }^{1}$ e determinadas funções, ofícios e ministérios, como os religiosos, envolvem o tratamento de questões sobre a intimidade do cliente ou paciente. ${ }^{2} \mathrm{O}$ bom desempenhar da profissão e o cumprimento de suas finalidades dentro da sociedade exigem, necessariamente, a discussão sobre fatos e informações que se inserem na esfera mais reservada do indivíduo, que até as pessoas mais próximas a ele podem desconhecer.

O profissional, como um advogado que presta assistência ao seu cliente, por exemplo, para poder lançar mão da melhor técnica disponível para o caso por ele apreciado, precisa saber de alguns pormenores que não podem ser revelados, salvo hipóteses excepcionais, sob pena de exposição ilícita de seu cliente.

Tendo essa realidade social como premissa, pode-se compreender a relevância da tutela estatal da intimidade e do sigilo profissional, proteção que parte desde os textos constitucionais até a regulamentação de certas atividades profissionais.

Neste breve trabalho, sem a pretensão de exaurimento, serão apresentadas, na primeira parte, questões como a tutela da intimidade, os motivos individuais e coletivos da proteção ao sigilo profissional, do confidente necessário e do objeto do segredo, além do direito positivo estrangeiro (Itália, Portugal, Espanha, Chile e Argentina) e do direito positivo brasileiro, desde o texto constitucional, até o regramento infralegal (portaria do Ministério da Justiça que trata da busca e apreensão em escritórios de advocacia).

Na segunda parte, serão abordados os reflexos processuais penais do sigilo profissional, especialmente no que tange à prova testemunhal e à busca e apreensão, sem deixar de se fazer, ao longo da exposição, observações quanto à profissão de advogados e médicos. Algumas inserções sobre o projeto de novo Código de Processo Penal em tramitação no Congresso Nacional (PLS n. 156/09) e acerca do Código de Processo Penal Tipo para a Iberoamérica também são realizadas nesse tópico.

Lembra Rodrigo Santiago que é equivocada a referência a segredo profissional jornalístico, pois as informações tratadas pelos jornalistas se destinam à divulgação e publicação. O que há é proteção da fonte da informação. (SANTIAGO, Rodrigo. Jornalistas e segredo profissional. Sub Judice Justiça e Sociedade, Lisboa, n. 15-16, p. 147-152, jun./dez. 1999. p. 149).

2 Sobre a distinção de profissão, função, ofício e ministério, v. PRADO, Luiz Régis. Curso de direito penal brasileiro. São Paulo: Revista dos Tribunais, 2008. v. 2. p. 318. 
2. Tutela da intimidade

Ainviolabilidade da intimidade tem, no Brasil, status de garantia fundamental da pessoa humana, como preceitua o art. $5^{\circ}, \mathrm{X}$, da Constituição da República. ${ }^{3} \mathrm{O}$ Estado procura propiciar efetividade a essa garantia mediante diversas normas, entre elas, a do sigilo profissional. O sigilo profissional é, portanto, parte da concretização da garantia fundamental de tutela da intimidade e, ainda, cumpre outras relevantes funções protetivas.

Ao tratar de defesa da intimidade, uma breve referência à teoria das três esferas se faz necessária. Explicada por Paulo José da Costa $\mathrm{Jr}_{\text {. }}{ }^{4}$ servindo-se da doutrina de Henkel, tal teoria propugna que cidadão teria sua vida privada separada da vida pública, sendo que a primeira se dividiria em três esferas concêntricas que se posicionariam de acordo com o grau de privacidade e de proteção estatal.

Seriam as esferas da vida privada stricto sensu, da intimidade ou confiança e a do segredo, cujas linhas separatórias seriam flexíveis ou elásticas, a depender dos contornos pessoais e sociais de cada indivíduo. ${ }^{5}$

A esfera mais externa seria a vida privada stricto sensu, na qual as relações e o compartilhamento de informações são circunscritas a um determinado número de pessoas que fazem parte de um mesmo meio, ficando excluídos da publicidade interna terceiros que não fazem parte do círculo. Os fatos e condutas do indivíduo não são de domínio público e, fora dela, situam-se as informações acessíveis a um número indeterminado de pessoas, à coletividade de modo geral.

Em um nível mais restrito, estaria a esfera da intimidade ou confiança, da qual participam um número menor de indivíduos conforme autorização e postura do indivíduo, que divide com tais integrantes fatos reservados não acessíveis aos integrantes da esfera da vida privada stricto sensu. Em suma, o indivíduo exige confiança e intimidade daqueles com quem compartilha suas posturas.

Por fim, a menor e mais central das esferas seria a do segredo. Nesta, fala-se de fatos extremamente íntimos da pessoa e ninguém ou pouquíssimas pessoas teriam acesso, as quais teriam dever de sigilo absoluto acerca das informações de que tiveram ciência, justamente pelo caráter íntimo e extremamente pessoal. Neste âmbito, há necessidade de proteção mais intensa.

A norma constitucional de garantia à intimidade diz também ser inviolável a vida privada e, com isso, percebe-se o amplo alcance que o constituinte quis oferecer

$3 \mathrm{CR}$, art. 5 (...): X - são invioláveis a intimidade, a vida privada, a honra e a imagem das pessoas, assegurado o direito a indenização pelo dano material ou moral decorrente de sua violação.

4 COSTA JÚNIOR, Paulo José da. $O$ direito de estar só. A tutela penal do direito à intimidade. 3. ed. São Paulo: Siciliano Jurídico, 2004. p. 34-35.

5 Id. Ibid., p. 36. 
à tutela do indivíduo. Como já mencionado, cuida-se de direito fundamental da pessoa humana ao qual, como aos demais direitos e garantias fundamentais, deve-se dar máxima efetividade. Como já dito, o sigilo profissional faz parte do plexo de proteção da efetividade das normas constitucionais referentes à intimidade e vida privada, daí a sua relevância nos âmbitos penal e processual penal.

\section{O sigilo profissional: motivos da proteção}

Quanto ao sigilo profissional, pode-se distinguir duas principais frentes de proteção: uma individual, relativa ao profissional, e outra coletiva ou social.

$\mathrm{O}$ sigilo profissional previne que a pessoa que desenvolve a atividade se torne um delator em potencial. Imagine-se o quão irracional seria se tudo que dissesse respeito à intimidade do paciente ou cliente fosse perquirido ao profissional, seja em uma demanda judicial cível, criminal ou qualquer outra situação. Agreguem-se, assim, ao impedimento ético inerente à atividade, do qual o profissional é ciente e treinado para cumprir, as normas jurídicas disciplinadoras do sigilo. No plano fático, se não houvesse sigilo, o profissional não conseguiria desenvolver seu mister e se tornaria uma fonte de informações sobre a vida alheia.

Ademais, o sigilo profissional tutela a confiança que a sociedade deposita no regular exercício das profissões. Neste ponto, soma-se à proteção individual do profissional um viés coletivo no alcance protetivo do sigilo. A sociedade necessita de certas profissões e o indivíduo tem a liberdade de escolher o profissional a quem recorrer e, assim, deve estar seguro de que encontrará resguardo da sua intimidade naquele ramo de atividade em que precise de assistência. ${ }^{6}$

\section{O confidente necessário}

$\mathrm{Na}$ visualização da relação individual entre cliente/paciente e profissional e na confiança pública sobre o bom desempenho das profissões, importante assinalar que o profissional caracteriza-se por ser um "confidente necessário", ou seja, presume-se que, para o bem daquele que o procura, para poder satisfazer à expectativa de seu cliente ou paciente, obrigatoriamente terá que saber de detalhes fáticos e pessoais que normalmente

Sobre o bem jurídico do crime de violação de sigilo profissional, previsto no art. 154 do Código Penal, v. GONZAGA, João Bernardino. Violação de segredo profissional. São Paulo: Max Limonad, 1976. p. 42. 
não seriam revelados. ${ }^{7}$ Portanto, o segredo é da natureza da profissão e núcleo de seu desenvolver cotidiano. ${ }^{8}$

O caráter de confidente necessário é logicamente percebido em profissões como a de advogado e médico. Essas profissões, vale enfatizar, são regulamentadas, ou seja, há lei ou normas das entidades federais que designam os parâmetros mínimos acerca do modo de exercício profissional. Assim, resguarda-se a sociedade e, da mesma forma, o próprio corpo profissional de maus profissionais ou de críticas que afetem o corpo profissional indistintamente.

Questão interessante diz respeito à análise do sigilo profissional em atividades em que o contratante e contratado se envolvem intimamente, como a de empregada doméstica, motorista, porteiro, caseiro, zelador, babá etc. A chave do encaminhamento da questão é o conceito de confidente necessário.

Como visto, nos casos em que exposição de detalhes ao profissional é inerente à atividade, sem o que o profissional não consegue desincumbir o seu mister conforme a expectativa social e de modo a satisfazer aos anseios de seu cliente, tem-se a figura do confidente necessário.

Embora os outros profissionais citados acima, mais circunscritos ao ambiente doméstico, entrem em contato íntimo com seus contratantes e possam ter acesso a informações delicadas sobre a vida deles, não se pode aduzir que o segredo seja indispensável ao exercício profissional. Assim, cai por terra o interesse estatal em tutelar tal segredo por meio de uma garantia de sigilo material e processual.

Ademais, normalmente, tais profissões não contam com regulamentação da atividade, o que dificulta o delineamento do objeto do sigilo e a compreensão social da necessidade de proteção.

Por fim, anote-se que tais profissionais não serão sujeitos ativos do delito de violação de sigilo profissional insculpido no art. 154 do Código Penal. Seria uma interpretação ampliativa do tipo penal, o que afronta a vedação à analogia in malan partem.

\footnotetext{
7 No caso do jornalista, ao contrário do que se verifica com o advogado e médico, não pode haver enquadramento como "confidente necessário", conforme Rodrigo Santiago. O autor explica a matriz francesa da expressão "confidente necessário”, que se distingue do confidente ocasional. (SANTIAGO, Rodrigo. Jornalistas e segredo profissional. Sub Judice Justiça e Sociedade, Lisboa, n. 15-16, p. 147-152, jun./dez. 1999. p. 151.)

8 Ao tratar do sigilo profissional, explica Miguel Reale Júnior: “O sigilo profissional do Advogado, externo ou interno, tal qual o do médico, é ponto central das normas deontológicas e legais que regulam a profissão". Prossegue o professor: "Com mais veemência, entre nós, Evandro Lins e Silva [Ética e sigilo profissional do advogado, Conferência Nacional da OAB, XVI, 1997, anais, p. 393-397] lembrando o art. 154 da Lei Penal acentua o caráter de 'confidente necessário' do Advogado em relação a seu cliente. Daí a inadmissibilidade da indiscrição e o fundamento de ordem pública que sustenta as regras estatuintes do sigilo". REALE JÚNIOR, Miguel. A relação advogado-cliente e o sigilo profissional como meio de prova. Revista do Advogado, São Paulo, ano XXIX, n. 104, p. 78-84, jul. 2009. p. 78-84.
} 
Assim, tais profissionais podem ser chamados a testemunhar em juízo e não poderão invocar a proteção do sigilo para deixar de falar aquilo que sabem acerca dos fatos, podendo ter suas condutas, em tese, enquadradas no delito de falso testemunho previsto no art. 342 do Código Penal.

Conclui-se que o profissional passível de enquadramento no conceito de confidente necessário, sobretudo se a regulamentação profissional tratar do resguardo do segredo profissional, estará acobertado pelo sigilo profissional e, ao revés, aquele que não se enquadra no conceito apresentado não poderá se servir do sigilo, em que pese o conhecimento de fatos íntimos do contratante.

\section{O segredo: objeto da proteção}

O segredo, que é o objeto do sigilo, consiste na informação relatada pelo interessado em ver seu problema analisado pelo profissional. São os fatos narrados em razão da relação profissional-cliente, sejam esses fatos honrosos, desabonadores, neutros ou até mesmo os fatos que não são os estritamente necessários para o deslinde do caso. ${ }^{9}$ Incluem-se sob o segredo, ainda, as informações obtidas com terceiros que não o cliente cujo conteúdo remeta à relação profissional e à intimidade do contratante.

Tais informações podem ser transmitidas ao profissional das mais diversas formas e não somente em uma reunião reservada. Aquilo que é dito por telefone ou escrito em mensagens eletrônicas, por exemplo, também é cercado pelo sigilo.

A doutrina informa que o segredo pode decorrer da natureza do fato, segundo a teoria objetiva ou do interesse sobre o conceito de segredo. Pode também se dar por força da vontade do titular daquela informação, conforme a teoria subjetiva ou da vontade. ${ }^{10} \mathrm{Em}$ outras palavras, os fatos podem indicar a necessidade do segredo ou a restrição de divulgação pode decorrer da manifestação de vontade do detentor da informação.

Quanto ao conteúdo de uma narrativa ou de documentos informados ao confidente necessário, presume-se a vontade de preservação do sigilo, justamente em razão da natureza da relação profissional-cliente. ${ }^{11}$ Essa é a expectativa coletiva e individual que recai sobre os profissionais, os quais, por outro lado, detêm, em tese, os parâmetros éticos e normativos de sua regular atuação. Assim, no que tange à duração, o segredo perdura mesmo após o término da prestação do serviço ou após a morte do interessado, podendo o profissional ser responsabilizado se o divulgar indevidamente.

9 GONZAGA, João Bernardino. Violação de segredo profissional. São Paulo: Max Limonad, 1976. p. 22.

10 Id. Ibid., p. 18.

11 Cf. SOBRINHO, Mário Sérgio; LAVACA, Thaís Aroca Datcho. Sigilo profissional e a produção de prova. In: FERNANDES, Antonio Scarance et al. (Coord.). Sigilo no processo penal: eficiência e garantismo. São Paulo: Revista dos Tribunais, 2008. p. 176. 


\section{Direito estrangeiro}

6.1. Itália

\section{O Codice di Procedura Penale contém dispositivo específico para elidir} certos profissionais da obrigação de depor sobre fatos que tenham tomado conhecimento no regular exercício da sua profissão (art. 200). ${ }^{12}$ Esses profissionais e os equiparados têm a faculdade de se abster de depor, mas o juiz, se entender que a alegação de sigilo profissional é infundada, pode determinar que a testemunha (profissional) deponha. ${ }^{13}$

O código citado contempla regra específica sobre buscas e apreensões em escritórios de advocacia, ${ }^{14}$ preocupando-se com o sigilo profissional para o resguardo

$12 \quad$ Art. 200. Segreto professionale

1. Non possono essere obbligati a deporre su quanto hanno conosciuto per ragione del proprio ministero, ufficio o professione, salvi i casi in cui hanno l'obbligo di riferirne all'autorità giudiziaria $(331,334)$ :

a) i ministri di confessioni religiose, i cui statuti non contrastino con l'ordinamento giuridico italiano;

b) gli avvocati, gli investigatori privati autorizzati, i consulenti tecnici e i notai;

c) i medici e i chirurghi, i farmacisti, le ostetriche e ogni altro esercente una professione sanitaria;

d) gli esercenti altri uffici o professioni ai quali la legge riconosce la facoltà di astenersi dal deporre determinata dal segreto professionale.

2. Il giudice, se ha motivo di dubitare che la dichiarazione resa da tali persone per esimersi dal deporre sia infondata, provvede agli accertamenti necessari. Se risulta infondata, ordina che il testimone deponga.

3. Le disposizioni previste dai commi 1 e 2 si applicano ai giornalisti professionisti iscritti nell'albo professionale, relativamente ai nomi delle persone dalle quali i medesimi hanno avuto notizie di carattere fiduciario nell'esercizio della loro professione (1957). Tuttavia se le notizie sono indispensabili ai fini della prova del reato per cui si procede e la loro veridicità può essere accertata solo attraverso l'identificazione della fonte della notizia, il giudice ordina al giornalista di indicare la fonte delle sue informazioni.

13 V. SOUZA, Diego Fajardo Maranha Leão de. Sigilo profissional e prova penal. Revista Brasileira de Ciências Criminais, São Paulo, v. 16, n. 73, p. 107-155, jul./ago. 2008. p. 126.

14 Art. 103. Garanzie di libertà del difensore.

1. Le ispezioni e le perquisizioni negli uffici dei difensori sono consentite solo:

a) quando essi o altre persone che svolgono stabilmente attività nello stesso ufficio sono imputati, limitatamente ai fini dell'accertamento del reato loro attribuito;

b) per rilevare tracce o altri effetti materiali del reato o per ricercare cose o persone specificamente predeterminate.

2. Presso i difensori e gli investigatori privati autorizzati e incaricati in relazione al procedimento, nonché presso i consulenti tecnici non si può procedere a sequestro di carte o documenti relativi all'oggetto della difesa, salvo che costituiscano corpo del reato.

3. Nell'accingersi a eseguire una ispezione, una perquisizione o un sequestro nell'ufficio di un difensore, l'autorità giudiziaria a pena di nullità avvisa il consiglio dell'ordine forense del luogo perché il presidente o un consigliere da questo delegato possa assistere alle operazioni. Allo stesso, se interviene e ne fa richiesta, è consegnata copia del provvedimento.

4. Alle ispezioni, alle perquisizioni e ai sequestri negli uffici dei difensori procede personalmente il giudice ovvero, nel corso delle indagini preliminari, il pubblico ministero in forza di motivato decreto di autorizzazione del giudice.

5. Non è consentita l'intercettazione relativa a conversazioni o comunicazioni dei difensori, degli investigatori privati autorizzati e incaricati in relazione al procedimento, dei consulenti tecnici e loro ausiliari, né a quelle tra i medesimi e le persone da loro assistite.

6. Sono vietati il sequestro e ogni forma di controllo della corrispondenza tra l'imputato e il proprio difensore in quanto riconoscibile dalle prescritte indicazioni, salvo che l'autorità giudiziaria abbia fondato 
do advogado e de seu cliente. A busca será possível para apuração de fato delituoso de apontada autoria do próprio advogado ou se este estiver ocultando elemento de prova relacionado ao crime em investigação. O objeto deve ser determinado e a busca se circunscreverá ao delito apurado. Sob pena de nulidade, o juiz deverá notificar o órgão de classe dos advogados para designação de membro que acompanhe a diligência. Se a diligência for determinada no curso da ação judicial, o juiz a acompanhará e, se anteceder a ação penal, tal incumbência é afeta a membro do Ministério Público. ${ }^{15}$

No direito material, o Codice Penale prevê o delito de Rivelazione di segreto profissionale (art. 622), ${ }^{16}$ cuja ação penal depende de representação do ofendido.

\subsection{Portugal}

O direito português oferece proteção ao sigilo profissional e, como diferencial, estabelece procedimento específico para a exceção de sigilo suscitada pela parte ou pela testemunha. Esse procedimento é denominado pela doutrina de incidente de quebra de escusa de depoimento, podendo ser afastado o sigilo face ao princípio da prevalência do interesse preponderante. ${ }^{17}$ Será ouvido no procedimento o órgão de regulamentação da profissão.

motivo di ritenere che si tratti di corpo del reato.

7. Salvo quanto previsto dal comma 3 e dall'articolo 271, i risultati delle ispezioni, perquisizioni, sequestri, intercettazioni di conversazioni o comunicazioni, eseguiti in violazione delle disposizioni precedenti, non possono essere utilizzati.

15 V. SOUZA, Diego Fajardo Maranha Leão de. Sigilo... cit., p. 126.

16 Art. 622: Rivelazione di segreto professionale

Chiunque, avendo notizia, per ragione del proprio stato o ufficio, o della propria professione o arte, di un segreto, lo rivela, senza giusta causa, ovvero lo impiega a proprio o altrui profitto, è punito, se dal fatto può derivare nocumento, con la reclusione fino ad un anno o con la multa da lire sessantamila a un milione. Il delitto è punibile a querela della persona offesa.

17 Código de Processo Penal, art. 135:

Segredo profissional

1 - Os ministros de religião ou confissão religiosa e os advogados, médicos, jornalistas, membros de instituições de crédito e as demais pessoas a quem a lei permitir ou impuser que guardem segredo podem escusar-se a depor sobre os factos por ele abrangidos.

2 - Havendo dúvidas fundadas sobre a legitimidade da escusa, a autoridade judiciária perante a qual o incidente se tiver suscitado procede às averiguações necessárias. Se, após estas, concluir pela ilegitimidade da escusa, ordena, ou requer ao tribunal que ordene, a prestação do depoimento.

3 - O tribunal superior àquele onde o incidente tiver sido suscitado, ou, no caso de o incidente ter sido suscitado perante o Supremo Tribunal de Justiça, o pleno das secções criminais, pode decidir da prestação de testemunho com quebra do segredo profissional sempre que esta se mostre justificada, segundo o princípio da prevalência do interesse preponderante, nomeadamente tendo em conta a imprescindibilidade do depoimento para a descoberta da verdade, a gravidade do crime e a necessidade de protecção de bens jurídicos. A intervenção é suscitada pelo juiz, oficiosamente ou a requerimento.

4 - Nos casos previstos nos ns. 2 e 3, a decisão da autoridade judiciária ou do tribunal é tomada ouvido o organismo representativo da profissão relacionada com o segredo profissional em causa, nos termos e com os efeitos previstos na legislação que a esse organismo seja aplicável. 
No direito material, o Código Penal prevê o delito de violação de segredo (art. 195) e o de aproveitamento indevido de segredo (art. 196). ${ }^{18}$

Quanto aos advogados, a Lei n. 15/2005 prevê o Estatuto da Ordem dos Advogados, que, em seu art. 87, versa sobre o sigilo profissional. Se o advogado declara algo com violação ao seu dever de sigilo, tal elemento de prova resta ineficaz (não faz prova em juízo). ${ }^{19}$

A lei processual ainda traz disciplina acerca da busca e apreensão em escritórios de advocacia e consultórios médicos, nos termos do art. 177, complementado

5 - O disposto nos ns. 3 e 4 não se aplica ao segredo religioso.

18 Art. 195. Violação de segredo.

Quem, sem consentimento, revelar segredo alheio de que tenha tomado conhecimento em razão do seu estado, ofício, emprego, profissão ou arte é punido com pena de prisão até 1 ano ou com pena de multa até 240 dias.

Art. 196. Aproveitamento indevido de segredo.

Quem, sem consentimento, se aproveitar de segredo relativo à actividade comercial, industrial, profissional ou artística alheia, de que tenha tomado conhecimento em razão do seu estado, ofício, emprego, profissão ou arte, e provocar deste modo prejuízo a outra pessoa ou ao Estado, é punido com pena de prisão até 1 ano ou com pena de multa até 240 dias.

19 Art. 87. Segredo profissional.

1 - O advogado é obrigado a guardar segredo profissional no que respeita a todos os factos cujo conhecimento lhe advenha do exercício das suas funções ou da prestação dos seus serviços, designadamente:

a) A factos referentes a assuntos profissionais conhecidos, exclusivamente, por revelação do cliente ou revelados por ordem deste;

b) A factos de que tenha tido conhecimento em virtude de cargo desempenhado na Ordem dos Advogados;

c) A factos referentes a assuntos profissionais comunicados por colega com o qual esteja associado ou ao qual preste colaboração;

d) A factos comunicados por co-autor, co-réu ou co-interessado do seu constituinte ou pelo respectivo representante;

e) A factos de que a parte contrária do cliente ou respectivos representantes the tenham dado conhecimento durante negociações para acordo que vise pôr termo ao diferendo ou litígio;

f) A factos de que tenha tido conhecimento no âmbito de quaisquer negociações malogradas, orais ou escritas, em que tenha intervindo.

2 - A obrigação do segredo profissional existe quer o serviço solicitado ou cometido ao advogado envolva ou não representação judicial ou extrajudicial, quer deva ou não ser remunerado, quer o advogado haja ou não chegado a aceitar e a desempenhar a representação ou serviço, o mesmo acontecendo para todos os advogados que, directa ou indirectamente, tenham qualquer intervenção no serviço.

3 - O segredo profissional abrange ainda documentos ou outras coisas que se relacionem, directa ou indirectamente, com os factos sujeitos a sigilo.

4 - O advogado pode revelar factos abrangidos pelo segredo profissional, desde que tal seja absolutamente necessário para a defesa da dignidade, direitos e interesses legítimos do próprio advogado ou do cliente ou seus representantes, mediante prévia autorização do presidente do conselho distrital respectivo, com recurso para o bastonário, nos termos previstos no respectivo regulamento.

5 - Os actos praticados pelo advogado com violação de segredo profissional não podem fazer prova em juízo.

6 - Ainda que dispensado nos termos do disposto no n. 4, o advogado pode manter o segredo profissional.

7 - O dever de guardar sigilo quanto aos factos descritos no n. 1 é extensivo a todas as pessoas que colaborem com o advogado no exercício da sua actividade profissional, com a cominação prevista no n. 5 .

8 - O advogado deve exigir das pessoas referidas no número anterior o cumprimento do dever aí previsto em momento anterior ao início da colaboração. 
pelo art. $180 .{ }^{20} \mathrm{~A}$ diligência será presidida pelo juiz com o acompanhamento do órgão de classe, não podendo ser colhida prova que afronte o sigilo profissional, sob pena de nulidade, salvo se objeto ou elemento de crime.

\subsection{Espanha}

$\mathrm{Na}$ Constituição espanhola há referência ao sigilo profissional, nos seguintes termos: art. 24, n. 2: "La ley regulará los casos en que, por razón de parentesco o de secreto profesional, no se estará obligado a declarar sobre hechos presuntamente delictivos". Em que pese promulgada em 1978, somente com o Código Penal de 1995 o ordenamento espanhol passou a tratar da matéria, com a previsão do crime de divulgação de sigilo profissional. ${ }^{21}$

A Ley de Enjuiciamento Criminal traz dispositivos sobre o tema e, curiosamente, estabelece, como regra, o dever aos profissionais de noticiar eventuais crimes, salvo exceções, dentro das quais não estão incluídos os profissionais da área da saúde. ${ }^{22}$

$20 \quad$ Art. 177. Busca domiciliária.

1 - A busca em casa habitada ou numa sua dependência fechada só pode ser ordenada ou autorizada pelo juiz e efectuada entre as $7 \mathrm{e}$ as 21 horas, sob pena de nulidade.

2 - Entre as 21 e as 7 horas, a busca domiciliária só pode ser realizada nos casos de:

a) Terrorismo ou criminalidade especialmente violenta ou altamente organizada;

b) Consentimento do visado, documentado por qualquer forma;

c) Flagrante delito pela prática de crime punível com pena de prisão superior, no seu máximo, a 3 anos.

3 - As buscas domiciliárias podem também ser ordenadas pelo Ministério Público ou ser efectuadas por órgão de polícia criminal:

a) Nos casos referidos no n. 5 do artigo $174^{\circ}$, entre as 7 e as 21 horas;

b) Nos casos referidos nas alíneas b) e c) do número anterior, entre as 21 e as 7 horas.

4 - É correspondentemente aplicável o disposto no n. 6 do artigo $174^{\circ}$ nos casos em que a busca domiciliária for efectuada por órgão de polícia criminal sem consentimento do visado e fora de flagrante delito.

5 - Tratando-se de busca em escritório de advogado ou em consultório médico, ela é, sob pena de nulidade, presidida pessoalmente pelo juiz, o qual avisa previamente o presidente do conselho local da Ordem dos Advogados ou da Ordem dos Médicos, para que o mesmo, ou um seu delegado, possa estar presente.

6 - Tratando-se de busca em estabelecimento oficial de saúde, o aviso a que se refere o número anterior é feito ao presidente do conselho directivo ou de gestão do estabelecimento ou a quem legalmente o substituir. Art. 180.

Apreensão em escritório de advogado ou em consultório médico

1 - À apreensão operada em escritório de advogado ou em consultório médico é correspondentemente aplicável o disposto nos ns. 5 e 6 do artigo 177.

2 - Nos casos referidos no número anterior não é permitida, sob pena de nulidade, a apreensão de documentos abrangidos pelo segredo profissional, ou abrangidos por segredo profissional médico, salvo se eles mesmos constituírem objecto ou elemento de um crime. (...)

21 Art. 199: 2. El profesional que, con incumplimiento de su obligación de sigilo o reserva, divulgue los secretos de otra persona, será castigado con la pena de prisión de uno a cuatro años, multa de doce a veinticuatro meses e inhabilitación especial para dicha profesión por tiempo de dos a seis años.

22 Arts. 416 e 417 :

Artículo 416

Están dispensados de la obligación de declarar: 
O Estatuto-Geral da Advocacia Espanhola ${ }^{23}$ trata da abstenção do dever de depor do advogado e de buscas e apreensões em escritórios. ${ }^{24}$

Peculiaridades que dizem respeito ao tema da lavagem de dinheiro merecem breve registro, ${ }^{25}$ as quais, todavia, não se cingem ao ordenamento espanhol, mas, ao contrário, alastram-se pela Europa a partir de diretrizes emanadas do Parlamento Europeu. A Lei n. 19/2003, que alterou a Lei n. 19/1993, inovou no cenário espanhol quanto ao regime da advocacia no tema do "blanqueo de capitales". A lei contempla um "catálogo de operações de risco" que, potencialmente, seriam utilizáveis com fins de lavagem de dinheiro, tais como constituição de sociedades unipessoais, pagamento com metais preciosos, administração de bens por pessoas residentes em paraísos fiscais, entre outras.

Assim como procuradores e notários, o advogado, em atividade de assessoramento (e não como mandatário em demanda judicial), passou a ser sujeito obrigado a tomar medidas preventivas no sentido da identificação do cliente e preservação de documentos no caso de uma possível operação destinada a lavar capitais.

$1^{\circ}$ ) Los parientes del procesado en línea directa ascendente y descendente, su cónyuge, sus hermanos consanguíneos o uterinos y los laterales consanguíneos hasta el segundo grado civil, así como lós parientes naturales a que se refiere el núm. $3^{\circ}$ art. 261. El Juez instructor advertirá al testigo que se halle comprendido en el párrafo anterior que no tiene obligación de declarar en contra del procesado; pero que puede hacer las manifestaciones que considere oportunas, consignándose la contestación que diere a esta advertencia.

$2^{\circ}$ ) El Abogado del procesado respecto a los hechos que éste le hubiese confiado en su calidad de defensor. $\mathrm{Si}$ alguno de los testigos se encontrase en las relaciones indicadas en los párrafos precedentes con uno o varios de los procesados, estará obligado a declarar respecto a los demás, a no ser que su declaración pudiera comprometer a su pariente o defendido.

Artículo 417

No podrán ser obligados a declarar como testigos:

$1^{\circ}$ ) Los eclesiásticos y ministros de los cultos disidentes sobre los hechos que les fueren revelados en el ejercicio de las funciones de su ministerio.

$2^{\circ}$ ) Los funcionarios públicos, tanto civiles como militares, de cualquier clase que sean, cuando no pudieren declarar sin violar el secreto que por razón de sus cargos estuviesen obligados a guardar, o cuando, procediendo en virtud de obediencia debida, no fueren autorizados por su superior jerárquico para prestar la declaración que se les pida.

$3^{\circ}$ ) Los incapacitados física o moralmente.

23 Real Decreto n. 658/2001.

24 Art. 32, 1 e 2:

Artículo 32

1. De conformidad con lo establecido por el artículo 437.2 de la Ley Orgánica del Poder Judicial, los abogados deberán guardar secreto de todos los hechos o noticias que conozcan por razón de cualquiera de las modalidades de su actuación profesional, no pudiendo ser obligados a declarar sobre los mismos.

2. En el caso de que el Decano de un Colegio, o quien estatutariamente le sustituya, fuere requerido en virtud de norma legal o avisado por la autoridad judicial, o en su caso gubernativa, competente para la práctica de un registro en el despacho profesional de un abogado, deberá personarse en dicho despacho y asistir a las diligencias que en el mismo se practiquen velando por la salvaguarda del secreto profesional.

25 V. SOUZA, Diego Fajardo Maranha Leão de. Sigilo profissional e prova penal. Revista Brasileira de Ciências Criminais, São Paulo, v. 16, n. 73, p. 107-155, jul./ago. 2008. p. 130. 
Embora o legislador espanhol tenha excluído o advogado da obrigação de informar o órgão competente em caso de suspeita de lavagem, com o fito de ilidir questionamentos quanto à violação da garantia do sigilo profissional, deve-se perquirir se as obrigações acima narradas já não são suficientes para enfraquecer as disposições acerca do sigilo, que, como visto, tutelam a intimidade do indivíduo e o profissional, tanto no aspecto individual como no da confiança das profissões.

Registre-se que a não adoção dos mecanismos preventivos apontados pela lei pode resultar na responsabilização do advogado como coautor ou partícipe do delito de branqueamento de capitais (art. 301 do CP espanhol), ${ }^{26}$ além de aplicação de sanção administrativa que podem chegar a $5 \%$ do faturamento do advogado ou seu escritório. ${ }^{27}$

\subsection{Chile}

As normas processuais chilenas eximem de prestar declarações as pessoas que, por sua profissão, estado ou função legal, tiverem o dever legal de guarda do segredo a elas confiado. Não podem ser compelidas, portanto, a revelar o conteúdo do segredo sabido em razão da profissão e a ilegal quebra do sigilo profissional acarreta a ilicitude da prova.

No direito material, o Código Penal Chileno (art. 247) prevê o delito de revelação de segredo profissional. No que se refere especificamente ao advogado, o Código de Ética do Abogado, de 2011, contempla o dever de confidencialidade. ${ }^{28}$

26 Artículo 301

1. El que adquiera, convierta o transmita bienes, sabiendo que éstos tienen su origen en un delito grave, o realice cualquier otro acto para ocultar o encubrir su origen ilícito, o para ayudar a la persona que haya participado en la infracción o infracciones a eludir las consecuencias legales de sus actos, será castigado con la pena de prisión de seis meses a seis años y multa del tanto al triplo del valor de los bienes.

Las penas se impondrán en su mitad superior cuando los bienes tengan su origen en alguno de los delitos relacionados con el tráfico de drogas tóxicas, estupefacientes o sustancias psicotrópicas descritos en los artículos 368 a 372 de este Código.

2. Con las mismas penas se sancionará, según los casos, la ocultación o encubrimiento de la verdadera naturaleza, origen, ubicación, destino, movimiento o derechos sobre los bienes o propiedad de los mismos, a sabiendas de que proceden de alguno de los delitos expresados en El apartado anterior o de un acto de participación en ellos.

3. Si los hechos se realizasen por imprudencia grave, la pena será de prisión de seis meses a dos años y multa del tanto al triplo.

4. El culpable será igualmente castigado aunque el delito del que provinieren los bienes, o los actos penados en los apartados anteriores hubiesen sido cometidos, total o parcialmente, en el extranjero.

27 V. SOUZA, Diego Fajardo Maranha Leão de. Sigilo... cit., p. 131.

28 V. ARANTES FILHO, Marcio Geraldo Britto. A regulamentação do sigilo das comunicações entre pessoas presentes e do sigilo profissional no direito processual penal chileno. Revista Brasileira de Ciências Criminais, São Paulo, v. 17, n. 80, p. 208-245 set./out. 2009. p. 236. Assim dispõe o Código de Ética do Abogado:

Título IV: Deber de confidencialidad 


\title{
6.5. Argentina
}

Por fim, anote-se observação sobre o direito processual penal argentino, que possui a seguinte regra:

\begin{abstract}
Art. 244. Deberán abstenerse de declarar sobre los hechos secretos que hubieren llegado a su conocimiento en razón del proprio estado, oficio o profesión, bajo pena de nulidad: los ministros de un culto admitido; los abogados, procuradores y escribanos; los médicos, farmacéuticos, parteras y demás auxiliares del arte de curar; los militares y funcionarios públicos sobre secretos de Estado.
\end{abstract}

\section{Direito Positivo brasileiro}

A disciplina normativa do sigilo profissional no Direito Positivo brasileiro se inicia na Constituição da República, que tutela a intimidade, vida privada, honra e imagem, além do sigilo da fonte necessário para o exercício profissional (art. $5^{\circ}$, X e XIV, da CR).

O Código Penal traz os delitos de "violação de segredo profissional", no art. 154, cujo sujeito ativo é quem exerce função, ministério ou profissão, e o de "violação de sigilo funcional", no art. 325, crime próprio de funcionário público, sendo que, ademais, a Lei n. 8.112/90 estabelece como dever do servidor guardar sigilo (art. 116, VIII).

O Código de Processo Penal estabelece, em seu art. 207, que são proibidos de depor, como testemunhas, os profissionais resguardados pelo sigilo profissional, salvo se desobrigadas pela parte interessada. Na mesma senda, é a previsão do art. 229, I, do Código Civil. O Código de Processo Civil escusa do dever de exibir documentos e coisa o profissional que deve guardar segredo, de acordo com o art. 404, IV, da Lei n. 13.105/15.

Uma breve referência à Lei n. 11.767, de 7 de agosto de 2008, que alterou o Estatuto da OAB (Lei n. 8.906/94) com intuito de enfatizar a inviolabilidade dos

\footnotetext{
§ 1. Deber de confidencialidad para con el cliente.

Artículo 46. Deberes que comprende el deber de confidencialidad. El deber de confidencialidad comprende: a) Prohibición de revelación. El abogado debe abstenerse de revelar la información cubierta por su deber de confidencialidad, así como de entregar, exhibir o facilitar El acceso a los soportes materiales, electrónicos o de cualquier otro tipo que contengan dicha información y que se encuentran bajo su custodia;

b) Deberes de cuidado. El abogado debe adoptar medidas razonables para que las condiciones en las que recibe, obtiene, mantiene o revela información sujeta a deber de confidencialidad sean tales que cautelen el carácter confidencial de esa información; y

c) Deber de cuidado respecto de acciones de colaboradores. El abogado debe adoptar medidas razonables para que la confidencialidad debida al cliente sea mantenida por quienes colaboran con él.

Artículo 47. Duración indefinida. El deber de confidencialidad no se extingue por el término de la relación profesional, la muerte del cliente, ni el transcurso del tiempo. Disponível em: <http://www. colegioabogados.cl/cgi-bin/procesa.pl?plantilla=/archivo.html\&bri=colegioabogados\&tab=art_1\&campo $=\mathrm{c} \_$archivo\&id=747>. Acesso em: 13 maio 2013.
} 
escritórios e dos meios de comunicação entre advogado e cliente, faz-se necessária, posto que profissional que lida com segredos do cliente como "confidente necessário". Abaixo, segue quadro com as alterações efetuadas, bem como com os dispositivos vetados.

O projeto de lei que resultou na lei em questão foi proposto na Câmara dos Deputados (PL n. 5.245/05), em 17 de maio de 2005, pelo deputado Michel Temer. Nesta época, muito se discutia sobre buscas e apreensões realizadas em escritórios de advocacia. Sem emendas de mérito, foi aprovado na Comissão de Constituição, Justiça e Cidadania, em 7 de dezembro de 2005 e, no Plenário, em 27 de março de 2006, quando foi remetido ao Senado Federal.

No Senado (PL n. 36/2006), foi aprovado na CCJ, em 9 de abril de 2008, sem emendas de mérito. Em 9 de julho de 2008, foi aprovado em Plenário, sendo remetido à sanção presidencial, fase do processo legislativo em que foram efetuados alguns vetos, conforme quadro abaixo.

\begin{tabular}{|c|c|}
\hline Lei n. 8.906/94 & Lei n. $11.767 / 08$ \\
\hline $\begin{array}{l}\text { Art. } 7^{\circ} \text { São direitos do advogado: } \\
\text { [...] } \\
\text { II - ter respeitada, em nome da liberdade de } \\
\text { defesa e do sigilo profissional, a inviolabilidade } \\
\text { de seu escritório ou local de trabalho, de seus } \\
\text { arquivos e dados, de sua correspondência e } \\
\text { de suas comunicações, inclusive telefônicas } \\
\text { ou afins, salvo caso de busca e apreensão } \\
\text { determinada por magistrado e acompanhada de } \\
\text { representante da OAB; } \\
\text { [...] }\end{array}$ & $\begin{array}{l}\text { Art. } 7^{\circ} \text { São direitos do advogado: } \\
{[\ldots]} \\
\text { II - a inviolabilidade de seu escritório ou local } \\
\text { de trabalho, bem como de seus instrumentos } \\
\text { de trabalho, de sua correspondência escrita, } \\
\text { eletrônica, telefônica e telemática, desde que } \\
\text { relativas ao exercício da advocacia; } \\
\text { [...] } \\
\S 5^{\circ} \text { (VETADO) }{ }^{31} \text { São instrumentos de trabalho } \\
\text { do advogado todo e qualquer bem móvel ou } \\
\text { intelectual utilizado no exercício da advocacia, } \\
\text { especialmente seus computadores, telefones, } \\
\text { arquivos impressos ou digitais, bancos de } \\
\text { dados, livros e anotações de qualquer espécie, } \\
\text { bem como documentos, objetos e mídias de } \\
\text { som ou imagem, recebidos de clientes ou de } \\
\text { terceiros. }\end{array}$ \\
\hline
\end{tabular}

29 Razões do veto: “A definição de instrumentos de trabalho, ao compreender 'documentos, objetos e mídias de som ou imagem, recebidos de clientes ou de terceiros', pode ensejar conseqüências indesejadas: de um 


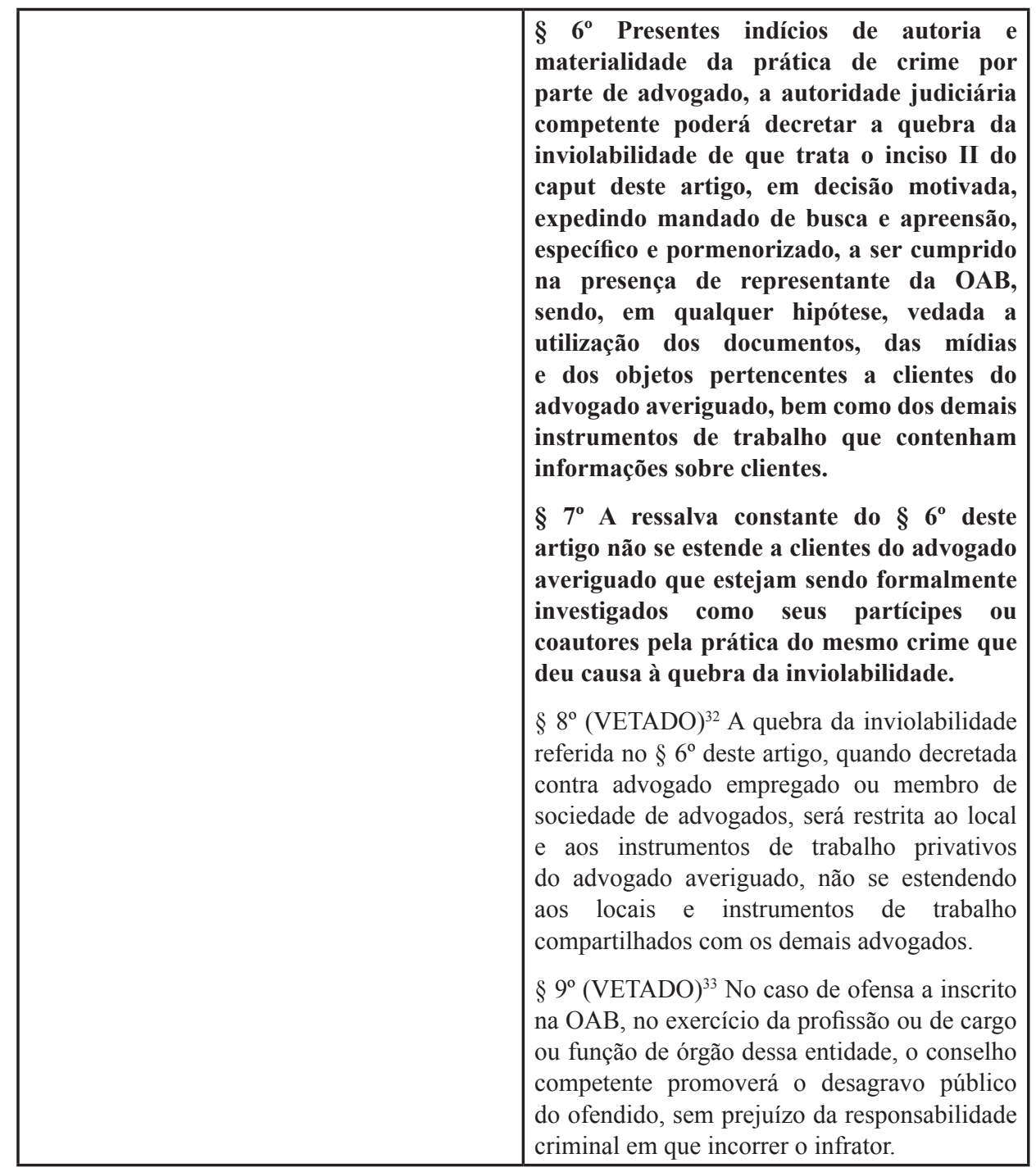

lado, clientes investigados poderiam, utilizando-se de artifício que extrapola os limites da relação clienteadvogado, valer-se da norma em questão para ocultar provas de práticas criminosas; de outro lado, a obtenção legítima de provas em escritórios de advocacia poderia ficar prejudicada, pois aumentaria sensivelmente a possibilidade de ataque à licitude das provas por sua potencial vinculação a 'clientes ou terceiros'."

30 Razões do veto: "A redação proposta para o $\S 8^{\circ}$ contém comando que pode inviabilizar a investigação criminal na hipótese de arquivos e documentos compartilhados em um escritório de advocacia. Ademais, a supressão do dispositivo em nada altera o resguardo do exercício profissional, uma vez que o acesso aos instrumentos de trabalho compartilhados em um escritório de advocacia não poderá extrapolar os limites do 
Antes mesmo da referida lei, o Ministério da Justiça editou a Portaria n. 1.288, de 30 de junho de 2005, que regulamenta as diligências da Polícia Federal de busca e apreensão nos escritórios de advocacia, no sentido de uniformizar a atuação e garantir as prerrogativas profissionais, entre as quais se destaca a proteção do sigilo profissional. Pelo ato, veda-se a busca decorrente de atos inerentes a atividade corriqueira do advogado.

\section{Reflexos processuais penais do sigilo profissional}

$\mathrm{O}$ direito à prova, como se sabe, não escapa ao respeito às garantias constitucionais do devido processo legal, ampla defesa, e contraditório.

Aliás, pode ser entendido como decorrência do contraditório, ou seja, o direito de se defender (ou acusar) provando. ${ }^{31}$

A Carta da República foi enfática ao estabelecer que o direito à prova se submete à legalidade, proscrevendo as provas obtidas por meios ilícitos (art. $\left.5^{\circ}, \mathrm{LVI}\right)$.

Nesse contexto, é condição de validade das provas sua produção em juízo, sob o pálio do contraditório, bem assim que, no tocante à prova oral, haja presença das partes em sua colheita. ${ }^{32}$

O estudo da admissibilidade das provas envolve, além das regras de inadmissibilidade por razões extraprocessuais (provas ilícitas e privileges), ${ }^{33}$ a exclusão de provas por motivos processuais e lógicos. ${ }^{34}$

Constituem regras que determinam a exclusão probatória por motivos processuais aquelas que disciplinam a (in)admissibilidade das provas visando à segurança

mandado judicial."

31 Magalhães Gomes Filho assevera que são titulares do direito à prova as partes do processo. Este direito engloba o direito à investigação; à proposição do meio de prova; à participação nos atos de produção, bem assim o direito à valoração da prova produzida (GOMES FILHO, Antonio Magalhães. Direito à prova no processo penal. São Paulo: Revista dos Tribunais, 1997. p. 85-89).

32 GRINOVER, Ada Pelegrini; GOMES FILHO, Antônio Magalhães; FERNANDES, Antonio Scarance. As nulidades do processo penal. 8. ed. São Paulo: Revista dos Tribunais, 2005. p. 146-148. Embora os autores se não restrinjam à prova oral a presença das partes como condição de sua validade, observa-se que no caso das provas pré-constituídas (documental, e.g.), sua produção não ocorre na presença das partes, sendo, nessa hipótese, diferido o contraditório. As partes, por via de regra, não acompanham a produção da prova pericial, cumprindo esse papel (quando indicados) seus assistentes técnicos. Sobre o contraditório na prova documental e pericial: GRINOVER, Ada Pelegrini. O conteúdo da garantia do contraditório. In: Novas tendências do direito processual. Rio de Janeiro: Forense Universitária, 1990. p. 26-31.

33 Privileges são normas de garantia a direitos individuais, podendo ser citado o witness privilege against selfincrimination (direito da testemunha à não autoincriminação) (DAMAŠKA, Mirjan R. Evidentiary barriers to conviction and two models of criminal procedure: a comparative study. University of Pennsylvania Law Review, Philadelphia, v. 121, p. 506-589, 1973. p. 521-524).

34 GOMES FILHO, Antonio Magalhães. Direito à prova... cit., p. 91-133. 
de um juízo de valor sobre determinado fato. Em nosso ordenamento, pode ser citado o art. 158 do Código de Processo Penal. ${ }^{35}$

No sistema da common law deve ser lembrada a exclusionary rule que não admite o testemunho de ouvir dizer (hearsay). ${ }^{36}$

Relevância e pertinência são critérios que levam à exclusão de provas por motivos lógicos.

Michele Taruffo ensina que relevante é a prova que almeja demonstrar o fato principal (materiality, consoante denominação da common law), bem como a que diz respeito à reconstrução histórica de um fato secundário, que logicamente pode interferir na reconstrução do fato principal (trata-se da relevancy no sistema da common law). A primeira hipótese é típica da prova direta e a segunda da indireta. ${ }^{37}$

Postas estas premissas, cabe asseverar que a natureza jurídica do sigilo profissional é mista, ou seja, penal material (seara em que é elemento normativo do tipo do art. 154 do Código Penal), deontológica (vem regulamentado pelos códigos de ética das mais variadas profissões), e processual, tanto civil quanto penal, interessando para este breve trabalho o último aspecto, não sendo analisadas as consequências processuais civis.

No âmbito processual penal, consoante lição de Magalhães Gomes Filho, o sigilo possui natureza de exclusão de prova por razões extraprocessuais. Aduz o autor que na ponderação de valores, o interesse social que está a embasar o segredo profissional deve preponderar sobre o interesse de obtenção probatória. ${ }^{38}$

Passemos, pois, a analisar as consequências do sigilo profissional na produção da prova testemunhal e na busca e apreensão.

35 Frederico Marques assevera ser essa regra verdadeira 'baboseira'. Já (GOMES FILHO, Antonio Magalhães. Direito à prova... cit., p. 97-98) possui posição diversa, defendendo que ela busca evitar equívocos por parte do julgador, acrescentando que na doutrina alemã esse tipo de vedação é denominada proibição de prova relativa. De qualquer forma, registre-se a originalidade de nosso ordenamento, único a possuir a norma do art. 158 do Código de Processo Penal.

36 DAMAŠKA, Mirjan R. Evidentiary barriers to conviction and two models of criminal procedure: a comparative study. University of Pennsylvania Law Review, Philadelphia, v. 121, p. 506-589, 1973. p. 514521.

37 TARUFFO, Michele. La prova dei fatti giuridici. Nozioni generali. Milano: Giuffrè, 1992. p. $337-339$.

38 GOMES FILHO, Antonio Magalhães. Direito à prova... cit., p. 129. Diego Leão de Souza, a seu turno, reflete que o sigilo possui natureza de regra de admissibilidade de prova, de proibição de prova e regra de exclusão probatória (SOUZA, Diego Fajardo Maranha Leão de. Sigilo profissional e prova penal. Revista Brasileira de Ciências Criminais, São Paulo, v. 16, n. 73, p. 107-155, jul./ago. 2008. p. 137-138). 
8.1. A prova testemunhal

$\mathrm{O}$ art. 207 do Código de Processo Penal, como visto, excepcionando a regra geral de que toda pessoa pode ser testemunha (art. 202), veda a produção de prova testemunhal em relação a fatos sobre os quais o depoente, em razão de função, ministério, ofício ou profissão, deva guardar segredo, salvo se, desobrigado pela parte interessada, quiser prestar seu depoimento.

Idêntica redação possui o texto do Projeto de Lei do Novo Código de Processo Penal (PLS n. 156/09). ${ }^{39}$

Tornaghi critica a redação do dispositivo, aduzindo que o emprego apenas da palavra "ofício" poderia ser satisfatório. Acrescenta que nem sempre é possível distinguir essas quatro categorias. Tentando fazê-lo, assevera que profissão é habitual e remunerada. "Ofício não pode ser uma coisa nem outra; a função é um múnus exercido sem caráter profissional e o ministério é desempenho altruístico de alto encargo assumido com a finalidade de servir a outrem". ${ }^{40}$

O dever de sigilo, conforme recorda Camargo Aranha, não deriva apenas de lei, mas também "de um regulamento disciplinador de uma atividade, (...) por força dos costumes (chaveiros, abridores de cofres etc.), ou então decorrente da própria natureza do ato praticado (cartomante, benzedeira, pai-de-santo etc.)". ${ }^{41}$

Nesse sentido, sustenta Aury Lopes Júnior que contador de uma empresa deve guardar sigilo sobre os fatos que tomou ciência ao exercer sua profissão. ${ }^{42}$

A escusa do sigilo profissional não desobriga a testemunha a comparecer em juízo. Se não o fizer, estará sujeita à condução coercitiva, bem assim ao pagamento de pena de multa, custas da diligência, sem prejuízo do processo penal por crime de desobediência (arts. 218 e 219 do Código de Processo Penal).

Deve, assim, atender ao chamado judicial e, na presença do juiz, quando indagada acerca de questão que envolva o sigilo profissional, recusar-se a depor invocando a proibição. ${ }^{43}$

39 "Art. 175. São proibidas de depor as pessoas que, em razão de função, ministério, ofício ou profissão, devam guardar segredo, salvo se, desobrigadas pela parte interessada, quiserem dar o seu testemunho" (texto aprovado pelo Senado em 7.12.10).

40 TORNAGHI, Hélio. Instituições de processo penal. 2. ed. São Paulo: Saraiva, 1978. v. 4. p. 78-79.

${ }^{41}$ ARANHA, Adalberto José Queiroz Telles de Camargo. Da prova no processo penal. 7. ed. São Paulo: Saraiva, 2006. p. 306.

42 LOPES JÚNIOR, Aury. Direito processual penal e sua conformidade constitucional. 5. ed. Rio de Janeiro: Lumen Juris, 2010. v. 1. p. 650.

43 Essa a redação do Codigo procesal Penal Modelo para Iberoamerica: "art. 172. Testimonio inadmisible. No podrán ser admitidas como testigos las personas que, respecto del objeto de su declaración, tengan el deber de guardar un secreto particular u oficial. En caso de ser citadas, deberán comparecer, explicar el motivo del cual surge la obligación de guardar secreto y abstenerse de declarar". 
Ainda que o fato se torne público, a obrigação de segredo permanece. ${ }^{44}$

Para a obrigação legal do segredo, desnecessária que a revelação tenha sido feita pelo próprio interessado, bastando que o depoente tome conhecimento do fato em razão de seu mister. ${ }^{45}$

Tornaghi levanta interessante questão: deve ser admitido o depoimento de quem tenha tomado conhecimento do fato por suas relações com o confidente? Como exemplo, menciona o caso de alguém que toma conhecimento de segredo de cliente de seu pai falecido manuseando seus documentos pessoais.

Adverte o autor que, na seara processual, a solução há de ser diversa da material, em que a resposta depende da redação da norma penal incriminadora. No direito processual, argumenta, "é permitida a interpretação compreensiva, a aplicação analógica e o recurso a princípios gerais de direito (Cód. Proc. Penal, art. $3^{\circ}$ ). É, portanto, necessário examinar o sentido e a razão de ser da lei. Esta não quer que o segredo confiado ao profissional seja levado a juízo. Permitir que um auxiliar, um parente, um herdeiro deste deponha sobre o que eventualmente soube por suas relações com ele será admitir por via oblíqua o que a lei proibiu, será fraudá-la, impedi-la de funcionar em muitos casos. Um médico, no leito de morte, conta à esposa gravíssimo segredo de um cliente. Consentir que a mulher fosse a juízo seria burlar a intenção da lei”" ${ }^{46}$

Evidentemente, o sigilo profissional não se estende aos profissionais incumbidos de descobrir segredos para revelá-los à justiça, como é o caso dos policiais. $\mathrm{O}$ mesmo se diga do funcionário público em geral com relação a seus subordinados. Sabendo de algo ilícito praticado por eles, ainda que no exercício da função, deve providenciar o necessário para sua devida responsabilização, sob pena de incursão nas penas do delito de condescendência criminosa (art. 320 do Código Penal). ${ }^{47}$

Saliente-se que a disposição legal em comento veda apenas o depoimento acerca de fatos conhecidos em razão da função, ministério, ofício ou profissão. Com relação a quaisquer outros, há o dever de depor.48

Assim, um advogado que, transitando pela rua, presencie um crime, por exemplo, possui o dever de depor, estando impedido, isto sim, de ser contratado pelo criminoso para defendê-lo acerca destes fatos. ${ }^{49}$

\footnotetext{
TORNAGHI, Helio. Instituições... cit., p. 79.

Id. Ibid., loc. cit.

Id. Ibid., p. 79-80.

Id. Ibid., p. 82.

48 ESPÍNOLA FILHO, Eduardo. Código de processo penal brasileiro anotado. 6. ed. Rio de Janeiro: Editora Rio, 1980. v. 3. p. 114.

49 MIRABETE, Júlio Fabbrini. Código de processo penal interpretado: texto atualizado até julho de 2003, referências doutrinárias, indicações legais, resenha jurisprudencial. 11. ed. São Paulo: Atlas, 2006. p. 567.
} 
Caso prestado depoimento com revelação de segredo profissional, terá havido a produção não só de uma prova ilegítima (em violação à norma processual ventilada), mas também ilícita (pôr em afronta à intimidade constitucionalmente tutelada - art. 5 X, da Constituição Federal - bem assim ao art. 154 do Código Penal, além de normas correlatas em leis diversas que regulamentam profissões variadas).

Entende-se, em apoio na lição de Ada Pellegrini Grinover, que, inspirada em Nuvolone, trouxe a distinção para o direito pátrio, que prova ilícita é aquela cuja obtenção infringe norma de direito material. Prova ilegítima, por sua vez, é a que cuja produção viola norma de direito processual. O primeiro vício ocorre quando da obtenção da prova; o segundo, no momento de sua produção. ${ }^{50}$

A ilicitude da prova conduz à inexistência do ato, devendo ser prova desentranhada do processo (não são admissíveis, não podendo no feito ingressar). $\mathrm{O}$ segundo leva à nulidade processual do ato de formação da prova, não necessitando ser desentranhada do feito, devendo novamente ser produzida de modo correto.

Acreditava-se que as provas ilegítimas, pelo fato de a sua obtenção já ser reprimida pelo direito material (sendo apenada com sanções civis, penais ou administrativas), eram processualmente admissíveis.

Este pensamento, porém, evoluiu, principalmente a partir da jurisprudência norte-americana, e hodiernamente é princípio universal a vedação das provas ilícitas. ${ }^{51}$

Como a violação do sigilo profissional redunda, além de ilegitimidade, ilicitude, a consequência, logo, deve ser o desentranhamento da prova constitucionalmente proscrita (art. 5 LVI, da Constituição Federal e art. 157 do Código de Processo Penal), não havendo que se falar em sua nova produção escorreita.

Importante frisar que, produzida prova contra constitutionem, ${ }^{52}$ permanecendo nos autos, não poderá embasar decisão judicial, sob pena de nulidade absoluta da sentença. ${ }^{53}$

Daí porque não é aceitável, em nosso direito, como bem explicitou Espínola Filho, a lição de Luís Osório, por ele referida, qual seja, de que "uma vez violado o

50 Esta sistematização, ao que se sabe, foi primeiramente feita na obra de GRINOVER, Ada Pelegrini. Liberdades públicas e processo penal - as interceptações telefônicas. São Paulo: Saraiva, 1976.

51 GRINOVER, Ada Pelegrini; GOMES FILHO, Antônio Magalhães; FERNANDES, Antonio Scarance. As nulidades do processo penal. 8. ed. São Paulo: Revista dos Tribunais, 2005. p. 154-161.

52 GRINOVER, Ada Pelegrini. Prova emprestada. Revista Brasileira de Ciências Criminais, São Paulo, n. 4, p. 60-69, 1993. p. 63-66.

53 Grinover obtempera que, nessa hipótese, poderá a sentença ser desconstituída por revisão criminal ou reformada em grau recursal, prolatando o juízo ad quem decisão substitutiva, desconsiderando a prova ilícita. (GRINOVER, Ada Pelegrini. Prova emprestada. Revista Brasileira de Ciências Criminais, São Paulo, n. 4, p. 60-69, 1993. p. 63-66.) 
segredo, uma vez feito o depoimento, nada impede que se lhe preste atenção, e se lhe dê o mesmo valor que teria se o depoente tivesse o direito de revelar o segredo". ${ }^{54}$

Especificamente acerca do sigilo profissional, há casos em que, excepcionalmente, será possível a produção válida de prova testemunhal que, aparentemente, implique violação do dever de sigilo.

Diego Leão de Souza faz algumas indagações: médico ou psicólogo que trate de um psicopata que lhe confessa o assassinato de diversas pessoas e a intenção de continuar a praticar crimes desta natureza poderia delatá-lo às autoridades competentes? $\mathrm{O}$ advogado que receba a informação de seu cliente de que um atentado contra grande número de civis está prestes a ocorrer não poderia legitimamente evitar o evento ${ }^{55}$

Costuma-se alvitrar que o legislador disponha, ainda que de modo exemplificativo, hipóteses extremas em que o profissional poderia, de modo lícito, revelar o segredo. ${ }^{56}$

No Brasil, como visto, a lei criminaliza a violação do sigilo profissional apenas quando não há justa causa para sua revelação (art. 154 do Código Penal).

Havendo justa causa, a conduta não é típica, de modo que possível a produção da prova tanto legal como legitimamente, ante a interdependência entre o dispositivo penal e o art. 207 do Código de Processo Penal. Realmente, a norma processual proíbe o depoimento apenas a respeito dos fatos sobre os quais o depoente deva guardar segredo. Havendo justa causa para sua revelação, cessa o dever de sigilo, pelo que legítimo o depoimento.

De se frisar que Códigos de Ética de profissões diversas preveem hipóteses em que o profissional está desobrigado do dever de sigilo.

$\mathrm{O}$ art. 25 do Estatuto da Advocacia, por exemplo, reza que "o sigilo profissional é inerente à profissão, impondo-se o seu respeito, salvo grave ameaça ao direito à vida, à honra, ou quando o advogado se veja afrontado pelo próprio cliente e, em defesa própria, tenha que revelar o segredo, porém sempre restrito ao interesse da causa".

O Novo Código de Ética Médica (Resolução CFM n. 1.931, de 17 de setembro de 2009, em vigor a partir de 13.4.10), dispõe:

\footnotetext{
54 ESPÍNOLA FILHO, Eduardo. Código... cit., p. 115.

55 SOUZA, Diego Fajardo Maranha Leão de. Sigilo profissional e prova penal. Revista Brasileira de Ciências Criminais, São Paulo, v. 16, n. 73, p. 107-155, jul./ago. 2008. p. 139.

56 GONZÁlEZ DE MURILlO, José Luis Serrano. Alcance del deber de secreto del profesional sanitario ante la administración de justicia penal. Revista Penal, Barcelona, n. 15, p. 137-149, jan. 2005. p. 142. Disponível em: < http://www.uhu.es/revistapenal/index.php/penal/article/viewFile/238/229>.
} 
É vedado ao médico:

Art. 73. Revelar fato de que tenha conhecimento em virtude do exercício de sua profissão, salvo por motivo justo, dever legal ou consentimento, por escrito, do paciente.

Parágrafo único. Permanece essa proibição: a) mesmo que o fato seja de conhecimento público ou o paciente tenha falecido; b) quando de seu depoimento como testemunha. Nessa hipótese, o médico comparecerá perante a autoridade e declarará seu impedimento; c) na investigação de suspeita de crime, o médico estará impedido de revelar segredo que possa expor o paciente a processo penal.

Art. 74. Revelar sigilo profissional relacionado a paciente menor de idade, inclusive a seus pais ou representantes legais, desde que o menor tenha capacidade de discernimento, salvo quando a não revelação possa acarretar dano ao paciente.

Art. 75. Fazer referência a casos clínicos identificáveis, exibir pacientes ou seus retratos em anúncios profissionais ou na divulgação de assuntos médicos, em meios de comunicação em geral, mesmo com autorização do paciente.

Art. 76. Revelar informações confidenciais obtidas quando do exame médico de trabalhadores, inclusive por exigência dos dirigentes de empresas ou de instituições, salvo se o silêncio puser em risco a saúde dos empregados ou da comunidade.

Art. 77. Prestar informações a empresas seguradoras sobre as circunstâncias da morte do paciente sob seus cuidados, além das contidas na declaração de óbito, salvo por expresso consentimento do seu representante legal.

Art. 78. Deixar de orientar seus auxiliares e alunos a respeitar o sigilo profissional e zelar para que seja por eles mantido.

Art. 79. Deixar de guardar o sigilo profissional na cobrança de honorários por meio judicial ou extrajudicial.

Dispositivos desta sorte, inscritos nos mais diversos códigos de ética profissionais, afiguram-se poderosos instrumentos para o intérprete averiguar a ocorrência de justa causa apta a afastar a obrigatoriedade de manutenção do segredo profissional.

Diante do elemento normativo do tipo penal do art. 154 do Código Penal ("sem justa causa"), força é convir que, no cenário nacional, é até mesmo dispensável 
socorrer-se da teoria da admissibilidade, por incidência do princípio da proporcionalidade, de provas ilícitas, a fim de se admitir a quebra do sigilo profissional em alguns casos. ${ }^{57}$

Cabe considerar, neste passo, ser fora de dúvida não configurar justa causa para revelação do segredo a mera intimação judicial para depor. ${ }^{58}$

De se frisar, ainda, que a obrigação do médico em comunicar doença de notificação compulsória, além de crime de ação pública incondicionada (salvo se a comunicação expuser seu paciente a procedimento criminal) (art. 269 do Código Penal e 66 , II, da LCP), não faz cessar a proibição de depor. ${ }^{59}$

Importante distinguir, porém, que o sigilo médico não abrange o profissional que exerce a função de perito (seja em processo judicial, administrativo ou inquérito policial). O experto, deve expor, no respectivo laudo pericial, suas conclusões, podendo também ser convocado a prestar esclarecimentos em juízo, inclusive sob pena de falsa perícia (art. 342, $\S \S 1^{\circ}$ e $2^{\circ}$ do Código Penal).

Marco Antonio de Barros aduz que até mesmo na esfera privada é possível haver hipóteses em que não há obrigação de sigilo, como os médicos contratados por empresas para proceder a exames trabalhistas que antecedem a contratação do empregado. ${ }^{60}$

Impende analisar se, autorizado pela parte interessada, o profissional ainda assim poderia se recusar a prestar o depoimento.

Aparentemente, e pela interpretação literal do art. 207 do Código de Processo Penal, possível entender-se que, se desobrigado pela parte interessada, é faculdade do profissional revelar ou não o segredo.

É inclusive o que recomenda o Código de Ética da Advocacia, em seu art. 26: "o advogado deve guardar sigilo, mesmo em depoimento judicial, sobre o que saiba em razão do seu ofício, cabendo-lhe recusar depor como testemunha em processo no qual funcionou ou deva funcionar, ou sobre fato relacionado com pessoa de quem tenha sido advogado, mesmo que autorizado ou solicitado por constituinte".

A justificar este entendimento, como verificado quando abordada a questão do bem jurídico tutelado pelo sigilo profissional, é pertinente dizer que o sigilo resguarda

57 Discute-se a possibilidade de se admitir prova ilícita invocando-se o princípio da proporcionalidade. Sustenta-se, amplamente, com base na garantia da ampla defesa e no princípio do favor libertatis, que é possível a admissão de prova ilícita pro reo. É questionável a invocação deste princípio contra a defesa. Scarance Fernandes diz que não se trata de ser o princípio utilizado contra ou a favor do acusado, mas de se verificar, na situação concreta, se a restrição imposta a algum direito do acusado é necessária, adequada e justificável em face do valor que se protege (FERNANDES, Antonio Scarance. Processo penal constitucional. 6. ed. rev., atual. e ampl. São Paulo: Revista dos Tribunais, 2010. p. 83-86).

58 ESPÍNOLA FILHO, Eduardo. Código... cit., p. 109.

59 TORNAGHI, Hélio. Instituições de processo penal. 2. ed. São Paulo: Saraiva, 1978. v. 4. p. 80-81.

60 BARROS, Marco Antônio de. A busca da verdade no processo penal. 2. ed. São Paulo: Revista dos Tribunais, 2010. p. 208. 
não só os interesses do particular, mas também a reputação e confiabilidade do profissional e da classe que ele representa.

Florian, a este respeito, aduz que

embora entendendo que o consentimento possa eliminar o crime, não poderá ele [o interessado] jamais coagir o depositário a revelar o segredo; aqui, não encontra mais aplicação a máxima volenti non fit injuria, porque se trata de uma faculdade concedida aos depositários do segredo, e não de um dever jurídico violado; pelo que, se os depositários estimam dever calar, a sua vontade deve ser respeitada, a despeito do consentimento de quem o confiou. ${ }^{61}$

No tocante ao advogado, giza Nucci que

muitas vezes, a liberação do dever de guardar segredo é pro forma, isto é, provocada por alguém - inclusive por autoridade policial ou judiciária - interessado em formar prova contra o cliente que, com o temor de parecer culpado pela negativa da desobrigação, termina concordando com o depoimento de seu ex-defensor, por exemplo. ${ }^{62}$

Aury Lopes Júnior acrescenta que o juiz e promotor de justiça também estão proibidos de depor sobre fatos de que tiveram conhecimento em razão da função (colhidos nos autos), ainda que desobrigados pela parte interessada. Todavia, poderão depor sobre fatos conhecidos extra-autos, estando, nestes casos, impedidos de atuarem profissionalmente (arts. 252, II, e 258, do Código de Processo Penal). ${ }^{63}$

Todavia, imagine-se que a prova a ser produzida pelo profissional, mesmo em violação do sigilo, é cabal para demonstração de inocência do réu.

Ora, como adverte González de Murillo, seria absurdo que uma regra destinada à proteção de alguém fosse utilizada em seu prejuízo. ${ }^{64}$

Refletindo sobre a questão, Diego Leão de Souza propõe algumas diretrizes para a colheita de prova testemunhal que envolva dever de sigilo profissional. ${ }^{65}$

61 FLORIAN, Eugenio. Delle prove penali. Milano: F. Vallardi, 1924. v. 2. p. 159, tradução livre.

62 NUCCI, Guilherme de Souza. Código de processo penal comentado. 8. ed. rev., atual. e ampl. São Paulo: Revista dos Tribunais, 2008. p. 468-469, nota 45.

63 LOPES JÚNIOR, Aury. Direito processual penal e sua conformidade constitucional. 5. ed. Rio de Janeiro: Lumen Juris, 2010. v. 1. p. 649-650.

${ }^{64}$ GONZÁLEZ DE MURILLO, José Luis Serrano. Alcance del deber... cit., p. 144.

65 SOUZA, Diego Fajardo Maranha Leão de. Sigilo profissional e prova penal. Revista Brasileira de Ciências Criminais, São Paulo, v. 16, n. 73, p. 107-155, jul./ago. 2008. p. 146-150. 
Primeiramente, recomenda que a alegação de escusa do depoimento deve passar pelo crivo do magistrado presidente da instrução. Caso a escusa seja manifestamente insubsistente, deve o juízo determinar o depoimento, sob as penas da lei. ${ }^{66}$

Nesse sentido, o Código de Processo Penal de Portugal prevê incidente de investigação de escusa, no já referido art. 135.

Sugere-se, ad cautelam, à falta em nosso ordenamento de norma semelhante à do direito português, que antes de determinar a prestação do depoimento, afastando-se a escusa de sigilo, que o juiz ouça o órgão de classe respectivo, o interessado no sigilo, e na sequência as partes.

Havendo renúncia ao sigilo por parte do interessado (vítima, réu ou terceiro), cabe ao profissional depoente fazer uma análise das consequências da revelação do segredo, surgindo daí três panoramas: a) prejudicará o réu; b) favorecerá o réu, mas prejudicará a vítima ou terceiros; c) favorecerá o réu sem prejudicar outrem.

Na primeira hipótese, ainda que confesso o réu, o profissional estará isento do dever de depor, devendo primar para que não seja conspurcada sua imagem profissional e de sua categoria. Caso deseje testemunhar, todavia, a prova será lícita e legítima, mas poderá o profissional responder administrativamente em seu órgão de classe por eventual infração ética.

No segundo cenário, novamente poderá o profissional fazer pleno uso de sua faculdade de não depor, incidindo aqui, pelas mesmas razões, o que foi dito no parágrafo anterior.

Por fim, no último caso, favorecendo a revelação do segredo o acusado, e não prejudicando ninguém a revelação do segredo, há dever de prestar o depoimento, não sendo aplicável a faculdade de abster-se de depor, o que redundaria a cominação das sanções cabíveis, inclusive crime de falso testemunho.

Acrescentamos que, nesta última hipótese, poderá haver revelação do segredo mesmo que não haja renúncia no interessado, pois patente a justa causa para sua prestação.

O mencionado autor aponta como única ressalva a este entendimento o sigilo a que estão obrigados os ministros religiosos, porquanto a manutenção do sigilo é imprescindível à manutenção da instituição a que pertence. Lembra que no direito português há absoluta inviolabilidade do sigilo dos sacerdotes e ministros de fé (art. 135, n. 4, do Código de Processo Penal). O Codex Juris Canonici, aliás, no Cânon 17, 5, § $2^{\circ}$,

$\overline{66}$ É o que prescreve o CPP Modelo para Iberoamerica: "173. Criterio judicial. Si el tribunal estima que el testigo invoca erróneamente la facultad de abstenerse o la reserva del secreto, ordenará su declaración. La resolución será fundada. Durante el procedimiento preparatorio decidirá el ministerio público, salvo en el caso del art. 258." 
n. 3, não desobriga o sacerdote do dever de guardar o segredo, mesmo quando liberado pelo penitente.

\title{
8.2. A busca e apreensão.
}

O Código de Processo Penal, que tanto se preocupou em resguardar o sigilo na produção de prova testemunhal, não o regulou ao disciplinar outros meios de prova e de obtenção de prova, notadamente a busca e apreensão.

Realmente, de nada adiantaria a tutela regulamentada na prova testemunhal, se não se entender seja ela extensível à busca e apreensão. Pense-se, por exemplo, na possibilidade de busca e apreensão de prontuários médicos, documentos guardados pelo advogado ou gravação das sessões de um psicólogo. Sendo lícitos estes procedimentos, espezinhado ficaria o sigilo profissional, mesmo que proibido o profissional de prestar depoimento. ${ }^{67}$

Magalhães Gomes Filho, nessa direção, defende a extensão da norma do art. 207 do Código de Processo Penal a outros meios de prova (documentos e perícias) que possam violar o segredo profissional..$^{68}$

Conclui-se, pois, que a busca e apreensão devem respeitar o sigilo profissional, sendo vedadas quando tiverem por objeto fonte de prova resguardada pelo sigilo, salvo se constituírem o corpo de delito, instrumento, produto ou proveito do crime.

Possível a aplicação por analogia, no processo penal (art. $3^{\circ}$ do Código de Processo Penal), do art. 403, IV, do Código de Processo Civil/2015, que dispõe poder se escusar a parte e o terceiro "de exibir, em juízo, o documento ou a coisa: (...) IV - se a exibição acarretar a divulgação de fatos, a cujo respeito, por estado ou profissão, devam guardar segredo". ${ }^{69}$

O Estatuto da Advocacia e da OAB (Lei n. 8.906/94) dispunha, em sua redação originária, no art. $7^{\circ}$, II, ser direito do advogado

\begin{abstract}
ter respeitada, em nome da liberdade de defesa e do sigilo profissional, a inviolabilidade de seu escritório ou local de trabalho, de seus arquivos e dados, de sua correspondência e de suas comunicações, inclusive telefônicas ou afins, salvo caso de busca e apreensão determinada por magistrado e acompanhada de representante da OAB.
\end{abstract}

\footnotetext{
${ }_{67}$ SOUZA, Diego Fajardo Maranha Leão de. Sigilo profissional... cit., p. 141.

68 GOMES FILHO, Antonio Magalhães. Direito à prova no processo penal. São Paulo: Revista dos Tribunais, 1997. p. 130.

69 Anote-se que idêntica redação possuía o art. 363, IV, do CPC/1973.
} 
Esta norma teve sua constitucionalidade declarada na ADIN n. 1.127/DF, julgada em 17.5.2006.

Como já se aludiu anteriormente, esta norma foi alterada pela Lei $n$. $11.767 / 08$, cujo texto fora transcrito alhures, sendo dispensável, neste passo, novos comentários a respeito.

Thaís Aroca Lacava e Mário Sérgio Sobrinho advertem que a presença de representante da $\mathrm{OAB}$ é extremamente relevante à fiscalização da diligência e garantia da não violação do sigilo profissional. ${ }^{70}$

Realmente, não é outra a razão da necessidade de acompanhamento do representante da $\mathrm{OAB}$, que, evidentemente, para resguardar a utilidade da diligência, não pode comunicá-la previamente ao sujeito passivo da busca, a menos que haja sua prévia intimação judicial, o que é difícil de ocorrer, pois no mais das vezes a surpresa é indispensável à viabilidade da diligência.

$\mathrm{O}$ art. 243, $\S 2^{\circ}$, do Código de Processo Penal, ainda, dispõe que "não será permitida a apreensão de documento em poder do defensor do acusado, salvo quando constituir elemento de corpo de delito".

Como lembra João Mendes, "não há justiça sem liberdade de defesa; e esta plenitude de defesa é um direito garantido pela Constituição". ${ }^{71}$

Evidente que a vedação de busca não se aplica quando o advogado é participante da infração, hipótese em que deve ser tratado como réu. ${ }^{72}$

A apreensão do bem quando constituir corpo de delito é imperiosa, lembrando-se que o exercício de seu mister não imuniza o advogado de praticar os delitos de receptação e favorecimento real (Código Penal, arts. 180 e 349). ${ }^{73}$

Em relação ao sigilo médico, discute-se se possível a determinação de exibição de documentos diversos, como prontuários médicos e resultados de exames, sob pena de desobediência e busca e apreensão.

Por primeiro, havendo autorização do paciente, nada impede que os médicos exibam os documentos requisitados pelo juízo, ${ }^{74}$ a menos que, por aplicação analógica do art. 207 do Código de Processo Penal, tenham por bem, de modo justificado, não quebrar o sigilo.

\footnotetext{
70 SOBRINHO, Mário Sérgio; LAVACA, Thaís Aroca Datcho. Sigilo profissional e a produção de prova. In: FERNANDES, Antonio Scarance et al. (Coord.). Sigilo no processo penal: eficiência e garantismo. São Paulo: Revista dos Tribunais, 2008. p. 171-201. p. 184.

71 Apud ESPÍNOLA FILHO, Eduardo. Código... cit., p. 199.

72 ESPÍNOLA FILHO, Eduardo. Código... cit., p. 199.

73 Id. Ibid, loc. cit.

74 SOBRINHO, Mário Sérgio; LAVACA, Thaís Aroca Datcho. Sigilo profissional... cit., p. 187.
} 
Ademais, sendo o médico ou profissional da saúde o investigado, não poderá opor justificativa de sigilo para não apresentar o documento. ${ }^{75}$

Não estão, ainda, acobertados pelo sigilo a mera ficha cadastral com os dados do paciente (nome, endereço, documento de identidade, CPF, entre outros dados). ${ }^{76}$

Consoante regra geral, para quebra do sigilo há que haver justa causa. Em não havendo, o médico possui o direito de não atender ordens desta espécie, não se afigurando justa causa a mera existência de ordem judicial.

Para defender seu direito, aliás, pode o médico inclusive impetrar habeas corpus preventivo para prevenir sua responsabilização pessoal por crime de desobediência e mandado de segurança para impedir que seus arquivos sejam submetidos à busca e apreensão. ${ }^{77}$

A análise da existência de sigilo profissional e de justa causa cabe ao julgador, alvitrando-se, assim como se fez quanto à produção de prova testemunhal, consulte previamente o respectivo órgão de classe, o interessado no sigilo e as partes do feito.

Recomenda-se ao juiz acentuada cautela ao determinar a obtenção do meio de prova em violação ao sigilo profissional, sob a justificativa de existir justa causa. Isso porque a ordem judicial não amparada por motivos idôneos poderá resultar em inadmissibilidade da prova derivada. ${ }^{78}$

Marco Antonio de Barros sugere que, em hipóteses excepcionais a justificar a quebra do sigilo, recomendável a disponibilização dos registros a um médico perito judicial. ${ }^{79}$

A orientação mostra-se pertinente, especialmente porque, muitas vezes, os prontuários são de difícil compreensão ao leigo e, ademais, o perito tornaria público apenas o que seja imprescindível à solução do feito, respondendo aos quesitos propostos, evitando-se, assim, eventuais excessos.

No tocante ao jornalista, inviável a busca e apreensão para descoberta da fonte, constitucionalmente protegida (art. $5^{\circ}$, XIV), a menos que o segredo possa ser revelado para proteger a liberdade física do indivíduo. ${ }^{80}$

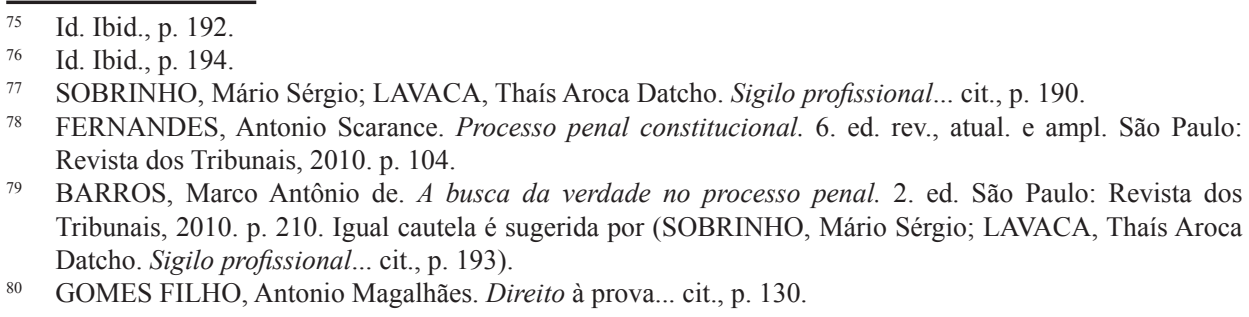

79 BARROS, Marco Antônio de. A busca da verdade no processo penal. 2. ed. São Paulo: Revista dos Tribunais, 2010. p. 210. Igual cautela é sugerida por (SOBRINHO, Mário Sérgio; LAVACA, Thaís Aroca Datcho. Sigilo profissional... cit., p. 193).

80 GOMES FILHO, Antonio Magalhães. Direito à prova... cit., p. 130. 
O Projeto de Lei do Novo Código de Processo Penal (PLS n. 156/09), procurando suprir lacuna da atual legislação, possui seção intitulada "Do Acesso a Informações Sigilosas" (Seção II do Capítulo III - Dos Meios de Obtenção de Prova), cujos artigos assim dispõem (texto aprovado pelo Senado em 7.12.2010):

Art. 241. O acesso a informações sigilosas, para utilização como prova no processo penal, dependerá de ordem judicial, devendo ser o pedido formulado pelo delegado de polícia ou pelo Ministério Público, na fase de investigação, ou por qualquer das partes, no curso do processo judicial, indicando:

I - a existência de indícios razoáveis da prática de infração penal que admita a providência;

II - a necessidade da medida, diante da impossibilidade de obtenção da prova por outros meios;

III - a pertinência e a relevância das informações pretendidas para o esclarecimento dos fatos.

Art. 242. Autuado o pedido em autos apartados e sob segredo de justiça, o juiz das garantias, na fase de investigação, ou o juiz da causa, no curso do processo penal, decidirá fundamentadamente em 48 (quarenta e oito) horas e determinará, se for o caso, que o responsável pela preservação do sigilo apresente os documentos em seu poder, fixando prazo razoável, sob pena de apreensão.

Art. 243. Os documentos que contiverem informações sigilosas serão autuados em apartado, sob segredo de justiça, sendo acessíveis somente ao juiz, às partes e a seus procuradores, que deles não poderão fazer outro uso senão o estritamente necessário para a discussão da causa.

Art. 244. A violação do dever de sigilo previsto nesta Seção sujeitará o infrator às penas previstas na legislação pertinente.

O Projeto, todavia, perde a oportunidade de trazer regulamentação específica acerca do sigilo profissional.

\section{Breve conclusão}

A tutela estatal do sigilo profissional, intimamente ligada à da intimidade, é universal nos Estados de Direito.

Sua efetivação passa pela mais variada gama de normas, sejam de índole constitucional, infraconstitucional - onde a regulamentação passa por normas de natureza 
vária (civil, penal, processual e administrativa) -, não se podendo olvidar que nem mesmo códigos de éticas de profissões múltiplas não descuraram do assunto.

Neste breve trabalho pretendeu-se analisar as implicações do sigilo profissional na prova penal, seara em que possui natureza de exclusão de prova por razões extraprocessuais.

Deu-se ênfase à prova testemunhal e à busca e apreensão, fazendose observações quanto à profissão de advogados e médicos, além de referências à regulamentação da matéria no Projeto de Código de Processo Penal em tramitação no Congresso Nacional (PLS n. 156/09).

Antes, porém, na primeira parte, como antecedentes lógicos, alinhavaramse problemas como a tutela da intimidade, os motivos individuais e coletivos da proteção ao sigilo profissional, do confidente necessário e do objeto do segredo, com alusões à regulamentação do direito positivo estrangeiro (Itália, Portugal, Espanha, Chile e Argentina) e do direito positivo brasileiro, desde o texto constitucional, até o regramento infralegal (portaria do Ministério da Justiça que trata da busca e apreensão em escritório de advocacia).

O objetivo foi traçar uma relação entre as áreas do direito material e processual e buscar uma sistematização do tema, que é complexo e demanda constante reflexão.

São Paulo, abril de 2016.

Referências

ARANHA, Adalberto José Queiroz Telles de Camargo. Da prova no processo penal. 7. ed. São Paulo: Saraiva, 2006.

ARANTES FILHO, Marcio Geraldo Britto. A regulamentação do sigilo das comunicações entre pessoas presentes e do sigilo profissional no direito processual penal chileno. Revista Brasileira de Ciências Criminais, São Paulo, v. 17, n. 80, p. 208-245 set./out. 2009.

AZEVEDO, David Teixeira. A invasão nos escritórios de advocacia: a corrosão da democracia. Boletim do Instituto Brasileiro de Ciências Criminais - IBCCrim, São Paulo, n. 153, p. 6-7, ago. 2005.

BARROS, Marco Antônio de. A busca da verdade no processo penal. 2. ed. São Paulo: Revista dos Tribunais, 2010.

BARROS, Marco Antônio de. Sigilo Profissional: reflexos da violação no âmbito das provas ilícitas. Revista Justitia, São Paulo, v. 58, n. 175, p. 17-33. jul./set. 1996.

COSTA, José de Faria. Os meios de comunicação (correios, telégrafo, telefones ou telecomunicações), o segredo e a responsabilidade penal dos funcionários. Boletim da Faculdade de Direito, Universidade de Coimbra, Coimbra, v. 72, 1996. 
COSTA JÚNIOR, Paulo José da. O direito de estar só. A tutela penal do direito à intimidade. 3. ed. São Paulo: Siciliano Jurídico, 2004.

DAMAŠKA, Mirjan R. Evidentiary barriers to conviction and two models of criminal procedure: a comparative study. University of Pennsylvania Law Review, Philadelphia, v. 121, p. 506-589, 1973.

DIAS, José Carlos. Sigilo profissional é proteção ao cidadão, não ao advogado. Consultor Jurídico - Conjur, [s.1.], jun. 2005. Disponível em: <http://www.conjur.com.br/2005-jun-17/sigilo_ profissional_protege_cidadao_nao_advogado>. Acesso em: 23 maio 2013.

ESPÍNOLA FILHO, Eduardo. Código de processo penal brasileiro anotado. 6. ed. Rio de Janeiro: Editora Rio, 1980. v. 3.

FERNANDES, Antonio Scarance. Processo penal constitucional. 6. ed. rev., atual. e ampl. São Paulo: Revista dos Tribunais, 2010.

FLORIAN, Eugenio. Delle prove penali. Milano: F. Vallardi, 1924. v. 2.

GOMES FILHO, Antonio Magalhães. Direito à prova no processo penal. São Paulo: Revista dos Tribunais, 1997.

GONZAGA, João Bernardino. Violação de segredo profissional. São Paulo: Max Limonad, 1976.

GONZÁLEZ DE MURILLO, José Luis Serrano. Alcance del deber de secreto del profesional sanitario ante la administración de justicia penal. Revista Penal, Barcelona, n. 15, p. 137-149, jan. 2005. Disponível em: <http://www.uhu.es/revistapenal/index.php/penal/article/viewFile/238/229>.

GREVI, Vittorio. O segredo como limite à prova no processo penal italiano. Ciência Penal, São Paulo, v. 2, n. 4, p. 3-23, 1975.

GRINOVER, Ada Pelegrini. O conteúdo da garantia do contraditório. In: . Novas tendências do direito processual. Rio de Janeiro: Forense Universitária, 1990. p. 26-31.

GRINOVER, Ada Pelegrini. Liberdades públicas e processo penal - as interceptações telefônicas. São Paulo: Saraiva, 1976.

GRINOVER, Ada Pelegrini. Prova emprestada. Revista Brasileira de Ciências Criminais, São Paulo, n. 4, p. 60-69, 1993.

GRINOVER, Ada Pelegrini; GOMES FILHO, Antônio Magalhães; FERNANDES, Antonio Scarance. As nulidades do processo penal. 8. ed. São Paulo: Revista dos Tribunais, 2005.

LOPES JÚNIOR, Aury. Direito processual penal e sua conformidade constitucional. 5. ed. Rio de Janeiro: Lumen Juris, 2010. v. 1.

MIRABETE, Júlio Fabbrini. Código de processo penal interpretado: texto atualizado até julho de 2003, referências doutrinárias, indicações legais, resenha jurisprudencial. 11. ed. São Paulo: Atlas, 2006. 
NUCCI, Guilherme de Souza. Código de processo penal comentado. 8. ed. rev., atual. e ampl. São Paulo: Revista dos Tribunais, 2008.

OLIVEIRA, Régis Fernandes de. Invasão de escritórios traz à tona crise de valores. Consultor Jurídico - Conjur, [s.1.], jun. 2005. Disponível em: <http://www.conjur.com.br/2005-jun-22/ invasao_escritorios_traz_tona_crise_valores $>$. Acesso em: 23 maio 2013.

PRADO, Luiz Régis. Curso de direito penal brasileiro. São Paulo: Revista dos Tribunais, 2008. v. 2.

REALE JÚNIOR, Miguel. A relação advogado-cliente e o sigilo profissional como meio de prova. Revista do Advogado, São Paulo, ano XXIX, n. 104, p. 78-84, jul. 2009.

SANTIAGO, Rodrigo. Jornalistas e segredo profissional. Sub Judice Justiça e Sociedade, Lisboa, n. 15-16, p. 147-152, jun./dez. 1999.

SOBRINHO, Mário Sérgio; LAVACA, Thaís Aroca Datcho. Sigilo profissional e a produção de prova. In: FERNANDES, Antonio Scarance et al. (Coord.). Sigilo no processo penal: eficiência e garantismo. São Paulo: Revista dos Tribunais, 2008. p. 171-201.

SOUZA, Diego Fajardo Maranha Leão de. Sigilo profissional e prova penal. Revista Brasileira de Ciências Criminais, São Paulo, v. 16, n. 73, p. 107-155, jul./ago. 2008.

TARUFFO, Michele. La prova dei fatti giuridici. Nozioni generali. Milano: Giuffrè, 1992.

TORNAGHI, Hélio. Instituições de processo penal. 2. ed. São Paulo: Saraiva, 1978. v. 4.

TORON, Alberto Zacharias; OLIVEIRA, Antônio Cláudio Mariz de; MACHADO, Rubens Approbato. Busca e apreensão em escritórios de advocacia. O Estado de S. Paulo, São Paulo, 30 jul. 2008, p. A2.

TOURINHO FILHO, Fernando da Costa. Código de processo penal comentado. 22. ed. São Paulo: Saraiva, 2000. v. 1. 